\title{
Studi Etnofarmasi Etnis Using Banyuwangi Indonesia
}

\author{
Nailis Syifa’*, Apris Dwi Sihdianto^, Adityo Herjuno^, Alvan Febrian Salash^ \\ *Program Studi Farmasi Fakultas Ilmu Kesehatan Universitas Muhammadiyah Malang \\ ${ }^{\wedge}$ Fakultas Farmasi Universitas Negeri Jember
}

Alamat Korespondensi : naily_sifa@yahoo.com

\begin{abstract}
ABSTRAK
Studi kebudayaan tentang metode pengobatan dan tanaman obat di suatu etnis penting untuk dipahami dalam rangka mengetahui perbedaan metode pengobatan serta tanaman obat yang digunakan dari masing-masing etnis. Selain itu studi ini juga bermanfaat untuk mengetahui obat dari bahan alam yang belum teridentifikasi. Dalam studi ini, sebagai obyek penelitian adalah etnis Using di Desa Kemiren, Kecamatan Glagah Kabupaten Banyuwangi. Metode yang digunakan dalam studi ini diantaranya adalah interview terhadap masyarakat serta orang-orang yang berperan dalam pengobatan tradisional di etnis tersebut. Hasilnya diperoleh informasi mengenai 62 tanaman obat yang biasa digunakan untuk pengobatan secara tradisional. Dari 62 tanaman tersebut kemudian dilakukan penggolongan berdasarkan bioaktivitasnya.
\end{abstract}

Kata Kunci : etnofarmasi, Indonesia, Banyuwangi, Suku Using, tanaman obat

\begin{abstract}
Cultural studies about treatment methods and herbal plants in an ethnic important to understand in order to know the different methods of treatment and medicinal plants used from each ethnicity. In addition, this study is also useful to know the drugs from natural ingredients that have not been identified. In this study, as the object of research is ethnic Using, Kemiren village, District Glagah Banyuwangi. The method used in this study include interviews with local community and the people who play a role in traditional medicine in these ethnic. The results obtained information on 62 commonly used medicinal plants for traditional medicine. From 62 plants were then performed classification based on the bioactivity.
\end{abstract}

Key word: Ethnopharmacy, Indonesia, Banyuwangi, Using Ethnic, Medicinal plant 


\section{LATAR BELAKANG}

Etnofarmasi adalah ilmu interdisipliner yang berkaitan dengan studi tentang kefarmasian dalam suatu etnis / kelompok masyarakat (Pieroni et al, 2002). Kegiatannya meliputi identifikasi, klasifikasi, dan ketegorisasi bahan alam dimana pengobatan mandiri berasal (etnobiologi), cara penyajian untuk sediaan farmasetika (etnofarmasetika), efek yang ditimbulkan dari sediaan tersebut (etnofarmakologi), dan efek sosiomedical dari penggunaannya (etnomedicine) (Pieroni et al, 2004).

Studi etnofarmasi ini dilakukan pada masyarakat Using Kabupaten Banyuwangi yang bertujuan untuk mengetahui tanaman obat yang berkhasiat sebagai pengobatan di etnis Using serta cara penggunaannya. Penelitian etnofarmasi ini penting untuk memberikan pemahaman yang lebih baik tentang perbandingan pengobatan modern dengan pengobatan dalam suatu etnis.

Keberadaan etnis Using sangat mencolok yaitu tersebar pada 20 kecamatan dari 24 kecamatan yang ada di Kabupaten Banyuwangi (Anonim, 2002). Desa
Kemiren, Kecamatan Glagah merupakan salah satu desa di Kabupaten Banyuwangi yang masih memiliki kebudayaan Using yang masih asli dan belum terkena dampak modernisasi. Oleh karena itu perlu diadakan studi terhadap salah satu kekayaan Using yang harus dilestarikan yaitu sistem pengobatan etnis Using.

\section{Tujuan Penelitian}

Memberikan data tentang budaya pengobatan dan data tanaman obat masyarakat Using Kabupaten Banyuwangi. Selain itu studi ini juga bermanfaat untuk mengetahui obat dari bahan alam yang belum teridentifikasi.

\section{METODE PENELITIAN}

Studi lapangan Etnofarmasi dilaksanakan di Desa Kemiren, Kecamatan Glagah Kabupaten Banyuwangi. Studi dilaksanakan pada kurun waktu 4 (empat) bulan. Informasi etnofarmasi diperoleh dengan beberapa metode yaitu interview narasumber dan responden., dokumentasi tanaman dengan menggunakan kamera digital dan recording, herbarium, dan studi

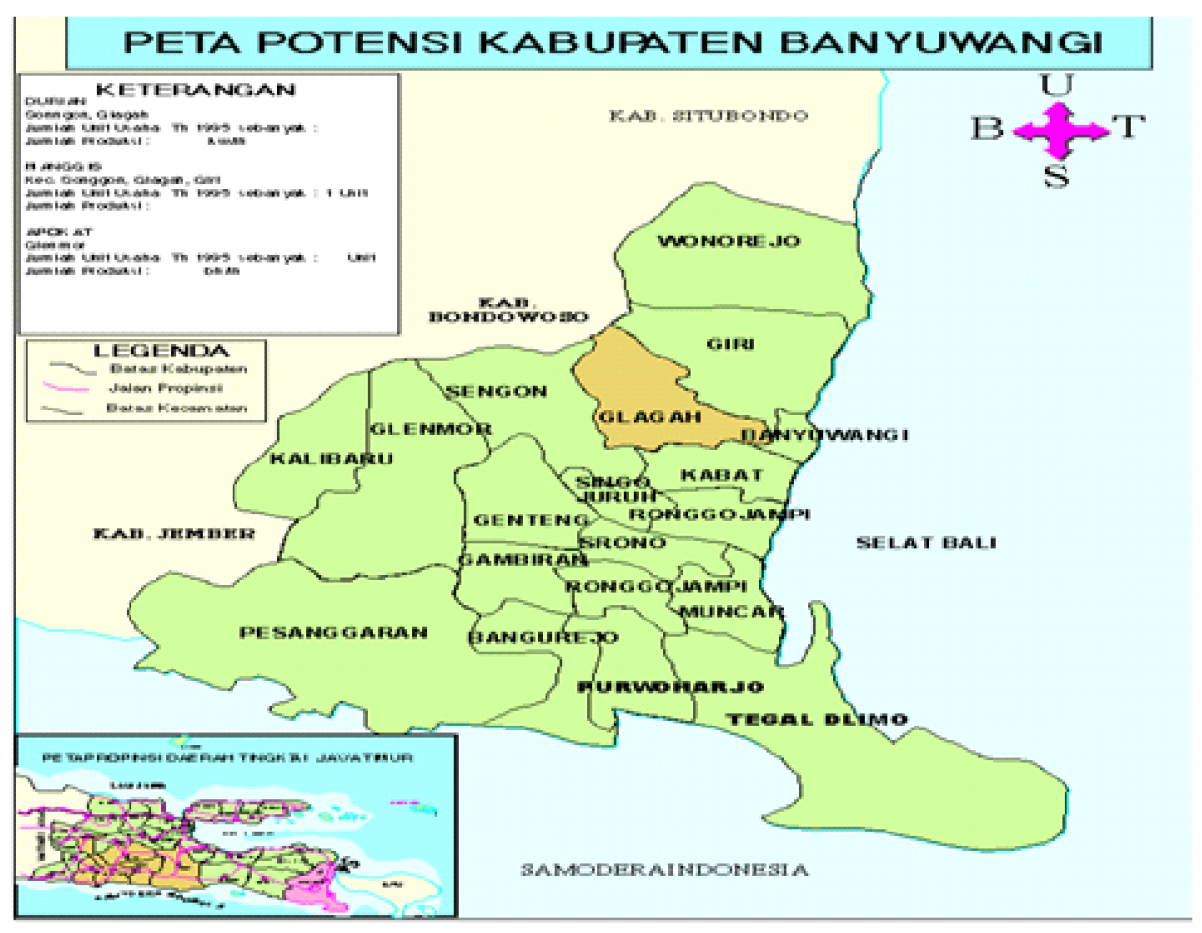

Gambar 1. Peta Kabupaten Banyuwangi 


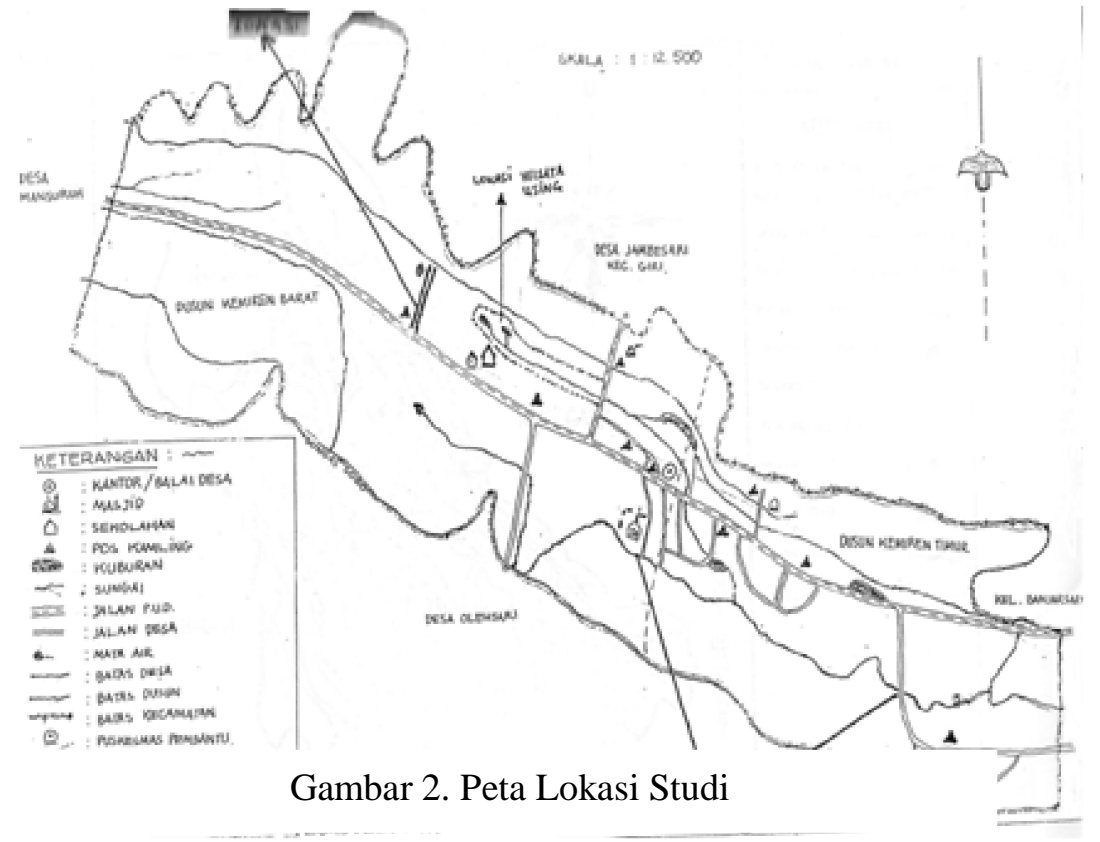

lapangan tanaman obat di daerah sekitar (Abel dan Kofi, 2005).

Interview narasumber difokuskan kepada tokoh masyarakat yang menguasai dan mengenal tradisi pengobatan menggunakan tanaman obat pada etnis tersebut. Proses identifikasi tanaman yang belum diketahui taksonominya dilakukan dengan cara pengamatan dan identikasi specimen tanaman ke Herbarium Jemberiense, Laboratorium Botani dan Kultur Jaringan, Jurusan Biologi Fakultas MIPA Universitas Jember.

\section{HASIL}

Dari hasil studi etnofarmasi ini, diperoleh 62 tanaman dari 35 famili yang digunakan sebagai pengobatan oleh masyarakat Using. Data disajikan pada Tabel 1. Data kemudian dikelompokkan menurut bioaktivitas tanaman yang disajikan pada diagram 1 .

Tanaman yang mempunyai prosentase penggunaan terbesar pertama dengan bioaktivitas sebagai analgesikantipiretik-antiinflamasi antara lain Carica papaya L., Plumeria rubra, Erythrina subumbrans Hask., Kaemferia galanga, Jatropa curcas L., Sesbania grandiflora Pers., Licuala sp.

Tanaman dengan prosentase penggunaan terbesar kedua yang digunakan untuk mengobati sakit perut oleh masyarakat Using antara lain Archidendron grandiflorum (Soland exex Benth.) LC. Nielsen, Salacca edulis Reinw., Allium sativum, Spillanthes acmella Murr., Pluchea indica L., Allium cepa, Gossypium herbaceum, Cocos nucifera, Ruellia tuberosa L., Moringa oleifera Lamk., Mikania micrantha H.B.

Tanaman dengan prosentase penggunaan terbesar ketiga yang digunakan untuk menyembuhkan luka dalam etnis Using antara lain Dioscorea esculenta, Carica papaya L., Jatropa curcas L., Pterocarpus indicus Willd., Plumeria rubra, Piper betle L., Ficus septica Burn. L.

\section{Pembahasan}

Pembahasan difokuskan pada tanaman yang memiliki prosentase penggunaan 3 terbesar, yaitu tanaman obat dengan khasiat Analgesik-AntipiretikaAntiinflamasi, penyembuh sakit perut, dan 


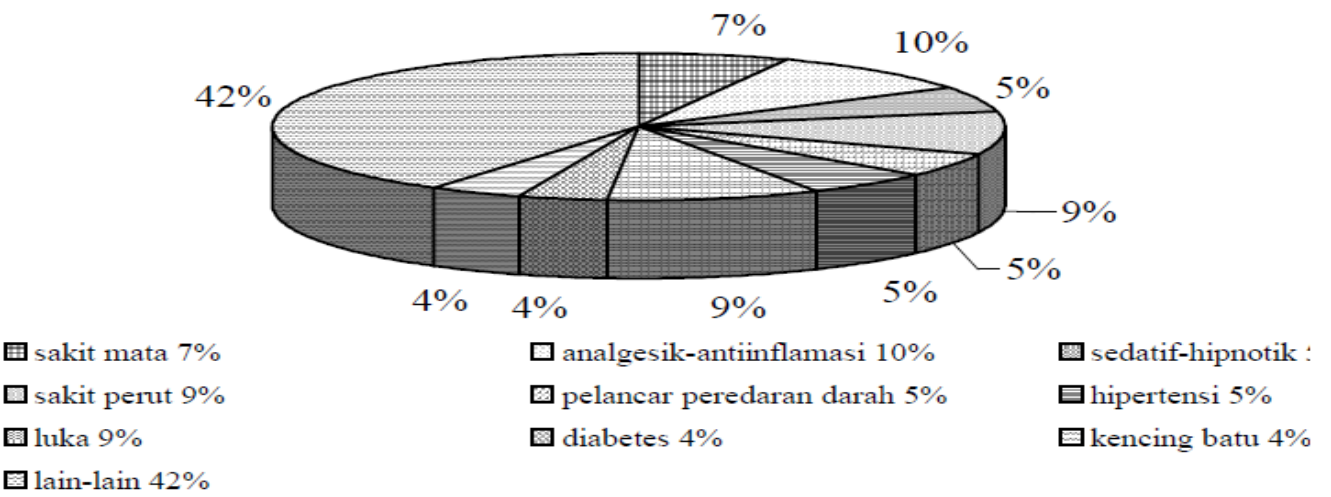

Diagram 1. Bioaktivitas Obat Tanaman Using

penyembuh luka. Penggunaan tanaman obat dari kategori diatas kemudian dibandingkan dengan data-data ilmiah yang ada, berhubungan dengan senyawa aktif, dan aplikasinya sebagai obat.

\section{Analgesik-antipiretik-antiinflamasi}

Carica papaya $\mathrm{L}$.

Daun pepaya diketahui mengandung enzim papain, alkaloid karpaina, pseudokarpaina, glikosida karposid, dan saponin. Penggunaan ekstrak daun pepaya telah dibuktikan secara ilmiah sebagai antipiretik (Anonim, 1989).

\section{Erythrina subumbrans Hask}

Daun dadap srep mengandung alkaloid eritradina, eritrina, eritramina, hipaforina, dan erisovina.Pengobatan empiris tersebut telah dibuktikan secara ilmiah dimana penggunaan daun dadap srep adalah untuk pengobatan pasca persalinan dan antipiretik (Anonim, 1989)

\section{Sakit Perut}

\section{Allium sativum}

Penggunaan umbi bawang putih telah dibuktikan secara ilmiah sebagai karminatif, ekspektoran, hipotensi, dan sedatif (Anonim, 1995). Allium sativum diketahui mengandung senyawa-senyawa seperti minyak atsiri, terpenoid sitral, geraniol, linalool, $\alpha \&$ felandren, sulfur, alylprophyl disulfida, dialyl disulfida, dialyl trisulfida, ajoene, protein, mineral, dan lemak. Umbi bawang putih telah terbukti dapat menekan kejang gastro-intestinal pada mencit yang diinduksi oleh minyak castor. Bawang putih juga menghambat asetilkolin dan $\mathrm{PGE}_{2}$, mengurangi kontraksi pada lambung tikus (Newall et al, 1996).

\section{Penyembuh luka}

Jatropa curcas L.

Masyarakat Using menggunakan jarak pagar sebagai pengering luka. Pengobatan empiris tersebut telah dibuktikan secara ilmiah dimana penggunaan jarak pagar adalah untuk mengobati bengkak-bengkak, encok, dan ketombe (Anonim, 1995)

Selain berbagai bioaktivitas yang telah disebutkan di atas, terdapat pula beberapa tanaman yang menarik untuk dikembangkan dan dilakukan penelitian lebih lanjut, diantaranya Emilia sonchifolia (L.) DC. (kemendilan.) untuk menyingsetkan payudara, Alpinia sp. (sempol) untuk mengobati tetes mata steril, Alternanthera sp (kelembak) sebagai sedatif-hipnotikum.

\section{KESIMPULAN}

Studi etnofarmasi masyarakat Using perlu dilanjutkan, mengingat tradisi pengobatan masyarakat Using dengan 
menggunakan tumbuhan sekitar masih dipercaya oleh masyarakat setempat, meskipun pengobatan tradisional tersebut saat ini telah tergusur sedikit demi sedikit oleh pengobatan modern. Terdapat \pm 62 jenis tanaman yang digunakan sebagai pengobatan oleh masyarakat Using dengan cara penyajian yang beraneka ragam. Hasil yang diperoleh dari studi ini dapat dijadikan sebagai titik awal penelitian lebih lanjut baik dari segi studi etnofarmasi maupun uji bioaktivitas tumbuhan obat yang sudah teridentifikasi, khususnya beberapa spesies yg menarik / prospektif untuk dikembangkan

\section{Daftar Pustaka}

Abel C, Kofi B. An Exploratory Ethnobotanical Study of the Practice of Herbal Medicine by the Akan People of Ghan. Journal of Alternative Medicine Review(10): 112-122.

Anonim. 1989. Materia Medika Indonesia Jilid V. Jakarta: Departemen Kesehatan Republik Indonesia.

Anonim. 1995. Materia Medika Indonesia Jilid VI. Jakarta: Departemen Kesehatan Republik Indonesia.

Anonim. 2002. Proposal Desa Wisata Using Kecamatan Glagah Kabupaten Banyuwangi, Paradigma Baru Pembangunan Desa. Banyuwangi: Yayasan Bina Wawasan Pariwisata Nusantara.

Hadi, Samsul Ir H. 2003. The HandBook To Tourism Object Of Banyuwangi. Banyuwangi: Dinas Pariwisata Seni dan Budaya Kabupaten Banyuwangi.

Khan S, Balick MJ. Therapeutic Plants of Ayurveda: A Review of Selected
Clinical and Other Studies for 166 Species. The Journal of Alternative and Complementary Medicine. 2001(7):405-515.

Newal, CA, Anderson LA, Phillipson JD. 1996. Herbal Medicines A Guide for Health-care Professionals. London: The Pharmaceutical Press.

Pieroni A, Quave C, Nebel S, Heinrich M. 2002. Ethnopharmacy of the ethnic Albanians (Arb, resh ${ }_{s}$ ) of northern Basilicata. Journal of Fitoterapia(73): 217-241.

Pieroni A, Quave C, Santoro RF. 2004. Folk Pharmaceutical knowledge in the territory of the Dolomiti Lucane, Inland southern Italy. Journal of Ethnopharmacology: 373-384. 